\title{
Does Conditional Conservatism affect the Cost of Capital? Evidence from China
}

\author{
Naveed Razzaq * Zhang Rui ${ }^{\dagger}$
}

\begin{abstract}
Conditional conservatism is strict verification of losses than gains and in timely recognition of earnings by reflecting bad news more quickly than good news. This study inspects the relation of conditional conservatism and the cost of capital. This paper examines whether timely loss recognition in financial reporting lowers the cost of capital in China A-Share listed enterprises registered in Shenzhen and Shanghai stock exchanges. This research analyse the penal data over the period 2002 to 2013. We find that conservatism reduces the cost of capital by decreasing dividend payoff, and conservatism reduces the agency conflict by reducing dividend payoff. Paper enhances the extant literature in same vein research by indulging different variables, sample size and period.
\end{abstract}

Keywords: Conditional conservatism cost of capital, agency conflict.

\section{Introduction}

Accounting conservatism became prominence later extensive debate among researchers, controllers and standards setters concerning its economic significances. More, Financial Accounting standards boards (FASB) and International Accounting Standards Board (IASB) declared and gave importance to faithfulness and neutrality in financial statements rather than conservatism. In spite of everything, academic workers elevated the significance of conservatism and claimed that conservatism is connected with higher quality of financial reporting. Further, Basu (1997); Givoly and Hayn (2000); Grambovas, Giner, and Christodoulou (2006) stated that accounting conservatism still increases our knowledge of accounting system and it existed since many years. In a recent study, Ruch and Taylor (2014) explained importance of accounting conservatism and an economic consequence, showed that accounting conservatism still is important.

The principle conservatism in accounting is appreciation of losses than gains (Bliss, 1924) "anticipated no profit but anticipate all the losses" (Watts, 2003). Consistently, the interpretation of the conservatism principle is timely reporting of losses or expenses as compare to the profit. The conservatism existence and its degree of existence vary in different explanations. Conservatism had existed in our accounting system from centuries; its importance and existence is increasing in accounting system from last three decades (Basu, 1997). He introduced to measure the accounting conservatism later on Khan and

\footnotetext{
${ }^{*}$ PhD graduate from Jiangxi University of Finance \& Economics. Currently, Lecturer at Department of Economics and Management, Xinyu University, Jiangxi, China. Email: naveed.razzaq@hotmail.com

† Professor at School of Accountancy, Jiangxi University of Finance \& Economics China. Email: jxufechen@163.com
} 
Watts (2009) portrayed a modified model from Basu (1997) model to measure accounting conservatism (by firm-year specific proxy of conditional accounting conservatism). They also explained contracting explanation and mechanism of accounting conservatism. Further, Ball, Kothari, and Robin (2000); Chung, Firth, and Kim (2003); Ball, Robin, and Wu (2003) described that accounting conservatism is accounting practices, rules and standards which is introduced in financial accounting.

Conservatism approach in financial reporting reduces the cost of capital through timely recognizing loss in accounting practices. Conservatism plays an integral role in accounting and financial management. Its importance has also been increasing in recent years. Authors are examining the importance of conservatism in accounting, how its existence is beneficial to reduce agency cost conflict and decreases the degree of information asymmetry in the debt market, manager's incentives, regulations and auditing to ease the firms performance.

Conservatism negatively explains the cost of capital which shows that timely loss recognition decreases the cost of capital by lessen dividend payoff. Conservatism diminishes the cost of capital of firms by mitigating managers incentives on negative projects and decreasing the dividend payoff. Along the same lines, for Chinese firms, conservatism causes a reduction in the cost of capital. Furthermore, Mohammed, Ahmed, and Ji (2010) documented that accounting conservatism is an important factor to enhance the quality of financial reporting. In an early study, (Easley \& O'hara, 2004; R. Lambert, Leuz, \& Verrecchia, 2007) enlightened that a good quality of accounting information and open disclosure may cause a decrease in the firm cost of capital.

Conservatism approach in financial reporting reduces the cost of capital. In line with existing research, accounting conservatism has helped to resolve agency problem which is discussed in Ball (2001); Kwon (2005); Xu, Wang, and Han (2012) research/thesis. Ball explained that managers normally have motivations to defer the termination of risky assignments (projects) because such assignments pay to an optimistic current earning and also provide personal benefits for the managers. On the other hand, with the implementation of accounting conservationism, future losses are quickly recognized by accountants, yet prevent the undertaking of negative Net Present Value projects for the sake of personal welfares, and therefore solve agency cost and moral hazard problems. Agency cost problems for example those debated in Watts (2003) and Ball (2001) especially ascend when the benefits of managers and shareholders are not associated with each other.

This paper predicts the accounting conservatism consequences on cost of capital in China A-Share listed companies registered in Shenzhen and Shanghai stock exchanges. We analyse the data of 6569 obs. over the period 2002 to 2013. Current paper examines conditional accounting conservatism's association with cost of capital. Our results are constant with the former researchers work. We find significant negative association of conditional conservatism and the cost of capital which suggests that conditional conservatism decreases the cost of capital in Chinese firms. This paper explains the association of accounting conservatism and the cost of capital in the perspective of Chinese economy. This may play its own role in extant literature of accounting conservatism and its association with cost of capital. Similarly, this paper is blurting out the importance of conditional accounting conservatism and the cost of capital nexus, and enhances the Chinese litera- 
ture. With deft economic growth and education (research and development) system of China, it undoubted that there are growing research opportunities. This proposed paper contributes the existing literature by using different time period of data sample with numerous variables In addition, the future prospective of this research is discussed in conclusion and can be used to explore this research's motivations.

\section{Literature Review}

Accounting literature reported evidence of implication of accounting conservatism on earnings quality. Some text explains that accounting conservatism is good predictor of earnings quality. Furthermore, cost of capital is a return which investors expect from the firm on their investments. The information asymmetry and contracting explanation between shareholders and managers may cause managers to change the reports in favour of themselves, to realize the good news before the bad news. Prior research documented mix evidence about managers and shareholders consensus about conservatism approach in accounting. Managers approach to realise bad news (losses) before gains limits their incentives to maximizing profit for shareholders. While Watts (2003); Kothari, Ramanna, and Skinner (2010) are of the point of view that this approach may under the high risk investment and not good for their successors (managers). The propagation of signals in accounting reports in the favour of mangers decisions, in the presence of asymmetric information of managers for future prospective and involvement of investors may cause of moral hazard and decrease manager opportunity behaviour. In a recent research, Lafond and Roychowdhury (2008) examined that investor's demand from firm for conservatism. They also investigated and find a negative relation among asymmetric timeliness of earnings and managerial or executives ownership.

Li (2015) examined that accounting conservatism in financial reporting reduces the cost of capital (cost of equity), further, her study found negative relationship between conditional accounting conservatism and the cost of capital in those economies where legal system very strong. The literature reviews different and numerous studies in recent and old literature, strive to embellish different analytical literature about relationship of accounting conservatism and the cost of capital. As reported by various recent empirical studies (Hail \& Leuz, 2007; Francis, LaFond, Olsson, \& Schipper, 2004; R. A. Lambert, Leuz, \& Verrecchia, 2011), they documented that voluntarily disclosure in financial statement may reduce the cost of capital. However, Gietzmann and Trombetta (2003) illustrated that accounting conservatism uses as an alternative for voluntary disclosure. Further, Bagnoli and Watts (2005) examines and state that accounting conservatism diminishes the cost of capital with same impact. In another study about managerial opportunist behaviour, Guay and Verrecchia (2007) reported evidence that conservative reporting decreases the manager's opportunistic behaviour and restrict managers from earning manipulation. Furthermore, they also find that conditional conservatism can decrease the cost of capital through decreasing discount rate. Different studies claimed that accounting conservatism improves information quality and enhance the information in disclosures (Q. Chen, Hemmer, \& Zhang, 2007; Gao, 2011) and their studies also contradict some 
others researchers research.

Instead of contradiction, Watts (2003) argued that accounting conservatism performs important role in debt contracting. In conservatism debtors are also compensated by offering low cost of borrowing because conservatism in reporting deftly generates contract violations (Ball \& Shivakumar, 2005; Zhang \& Wu, 2011). That's why conservatism refer as useful and effective approach in debt contracting. Accordingly, Zhang and Wu (2011) argued that conservatism reduces the borrower cost of borrowing and Lara, Osma, and Penalva (2011); Li (2015) reported that accounting conservatism has relationship with lesser the cost of equity. Lately, Artiach and Clarkson (2011) also document a relationship of accounting conservatism and the cost of capital and depend on firm's information environment. In addition, the analyses at country level find negative relationship of accounting conservatism with cost of capital is stronger for countries where less independent directors and dependent directors board (Li, 2015).

This study investigates conservatism relationship with cost of capital. Prior study examined that conservatism diminishes the cost of capital by decreasing interest rate and decreasing dividend payoff. This study reckon out that conditional conservatism decreases the cost of capital by lessen dividend payoff. In line with LaFond and Watts (2008) and Lara et al. (2011) found that conditional conservatism lessens the information asymmetry and the Cost of capital (cost of equity). Similarly, Li (2015) also stated that conservatism approach in financial statement reduces the cost of capital. Current study also finds that accounting conservatism reduces the cost of capital in China. Further, we find negative relationship of the cost of capital with dividend payoff, and positive association with leverage and returns on assets (ROA). By Robust test analysis, we also found that conditional conservatism reduces dividend payoff which infers that conservatism resolve the agency conflict between creditors and lenders. This study claims that conservatism firms may less likely to pay dividend payoff. Similarly, B.-W. Chen C and Zhu (2012) conducted research on Chinese data sample and found that conservative firms in China are paying fewer dividends. Herein, we additional elevated certain query that how conditional accounting conservatism influences to reduces the cost of capital? How conservatism lessen the cost of capital? Does this paper figure out economic consequences of accounting conservatism and significance in emerging economy needs to undo? Contemporary article will further divided on research design and sample, which will be explained in the upcoming sections.

\section{Research Design}

The fragment of the paper will define the econometric models under inspection for the conservatism association with the cost of capital. This paper model description is based on former studies (Lara et al., 2011; R. A. Lambert et al., 2011; Khalifa \& Ben Othman, 2015) investigated conditional conservatism association with cost of capital. First, we calculate the conservatism by employing a Basu (1997) model with minor alterations (Khan \& Watts, 2009) at year firm level. Second, we study the relationship of conditional accounting conservatism with the cost of capital (cost of equity), comprising the data sam- 
ple size organised for this paper. This study measures the cost of capital by using Ohlson and Juettner-Nauroth (2005) or OJ-Model.

\section{Hypothesis Development}

This paper examines the conditional accounting conservatism timeliness information recognition (losses than gains) relationship with cost of capital. Prior research documented that information asymmetry, timely reporting of losses than profits are reducing the cost of capital. Therefore, we hypotheses that conditional accounting conservatism reporting is causes to lessen the cost of capital with consistent of the prior research that accounting conservatism information asymmetry is decrease the cost of capital to anticipate the losses rather than profits in financial reporting. Gigler, Kanodia, Sapra, and Venugopalan (2009) examined that lenders want conservative reporting and conservatism associated with to reduce the cost of equity and debt capital. Lara et al. (2011); R. A. Lambert et al. (2011); Khalifa and Ben Othman (2015) researched that conservatism had impacted on cost of capital and their results depicted that conservatism diminishes the cost of capital. Thus, this study develops a hypothesis that accounting conservatism reduces the cost of capital (cost of equity) for firms in China. Conservatism is facilitating firms by giving access to external resources at lower rate of interest and reducing dividend pay-out. We are expecting negative relationship between conditional conservatism and the cost of capital (Francis et al., 2004; Chan, Lin, \& Strong, 2009; Lara et al., 2011; R. A. Lambert et al., 2011; Li, 2015; Khalifa \& Ben Othman, 2015).

$H_{0}$ : Accounting conservatism reduces the firms cost of capital (cost of equity).

\section{Research Methodology}

Conservatism has an integral role in accounting practices and existing in our accounting systems from many decades (Basu, 1997). Accounting conservatism has importance in indicating earnings quality by a standard book (Chan et al., 2009). Further, conservative firms may associate with higher quality of earnings, so lessen the cost of capital by normative accounting theory (Chan et al., 2009). Former research documented the relationship of conservatism and cost of capital and its economic consequence. This study also investigates conditional conservatism reduces the cost of capital in context of Chinese economy.

\section{Data Sample Selection}

It anticipated in this study to scrutinize conservatism relationship with cost of capital by employing accounting data. The data has taken out from annual reports of A-Share listed enterprises registered in the Shenzhen and Shanghai stock exchanges. All data is available at CSMAR database, a famous database for Chinese companies. Agency of China Securities Regulation Commission (CSRC) is governing all listed enterprises and handles information such as stock issues, annual or semi-annual or quarterly reports. It composed data of non-financial 2544 firms for the period of 2002-2013 from 15 different sectors, only selected those industries in which there were more than 15 companies in each industry. 
This paper only includes non-financial firms data because of variable firm construction, investment setting and accounting actions of financial firms. Initially, our data sample was consisting of 20040 obs. Later on, this panel data consists of 6569 observations after elimination of incomplete observations and estimation. In addition detail of all variables is given in table 1 .

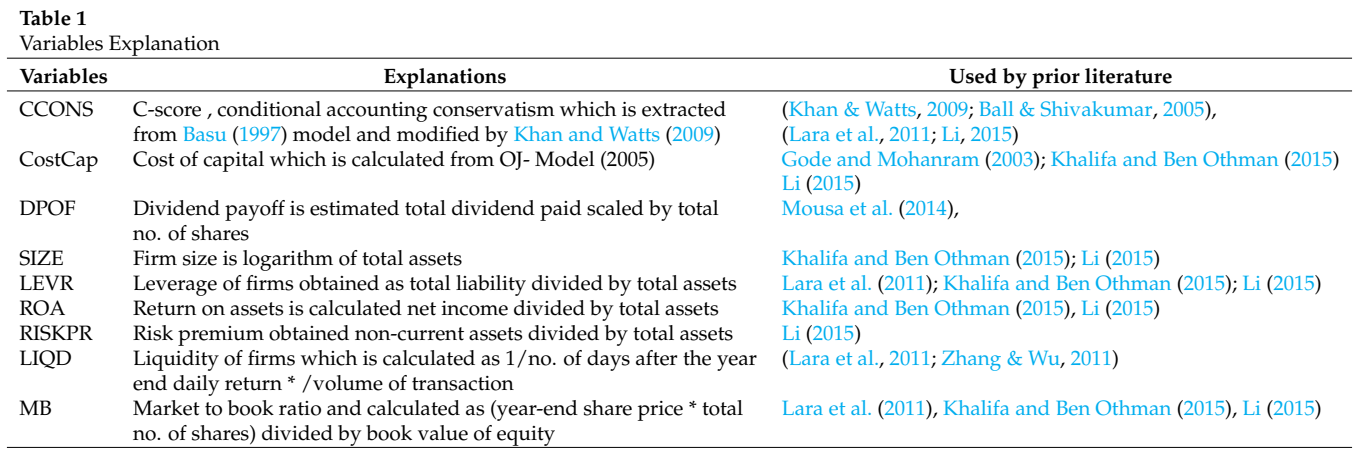

\section{Measurement of Conservatism and Cost of Capital}

Formerly, two approaches persisted well-known to estimate conservatism and based on accounting measures. First approach, asymmetric timeliness of earnings presented by Basu (1997), though the second was accrual based approach invented by Givoly and Hayn (2000). Conversely, these conservatism measurement approaches (methods) are based on accounting actions of firm performance. In this article, first we calculate the timely recognition of loss than profit based on accounting measure C-Score (Basu, 1997). He explored earnings which are related with bad news (negative return) and good news (positive return), addition, well-defined conservatism as the more stern verifiability appropriateness for the appreciation of gains comparative to losses into accounting earnings (Basu, 1997). Constantly, we do practice the valuation by focusing standard model (Basu, 1997) and analyse incremental timeliness coefficient that enhanced the conditional accounting conservatism (CCONS). This valuation helps to find the presence of accounting conservatism in financial reporting of Chinese firms, which further led to analyse conditional conservatism (CCONS) with cost of capital employing control variables.

Secondly, paper follows the Ohlson and Juettner-Nauroth (2005) method or abnormal earning evaluation model to calculate the cost of capital. This valuation formula expresses the cost of capital as a function of the forward eps to price ratio and the two measures of growth in expected eps. Another reason to select this model for cost of capital is that some researcher documented that Ohlson and Juettner-Nauroth (2005) is best for emerging and developing market. Gode and Mohanram (2003) research shows that OJ-Model gives a good valuation of the cost of capital. Further, to calculate cost of capital by OJ-model, we need to calculate few accounting variables as compare to other cost of capital evaluation models. The main feature of OJ-Model is to introduce the expected earnings per share into firm valuation. 


\section{Econometric Model of Conservatism and the Cost of Capital}

The association of accounting conservatism with cost of capital is that timely recognition of earnings decreases the cost of capital by reducing dividend payoff and by providing lower interest rate on external funds. Previous research, (Francis et al., 2004; Chan et al., 2009; Lara et al., 2011; R. A. Lambert et al., 2011; Li, 2015; Khalifa \& Ben Othman, 2015) showed the association of conservatism and cost of capital, and documented that accounting conservatism reduces the cost of capital (cost of equity and cost of debt) and developed a hypothesis that conservatism reduces the cost of capital. Furthermore, conservatism reduces the dividend payoff and may resolve the agency conflict. This study portrays a model to encapsulate the impacts of conditional conservatism on cost of capital.

$$
\begin{array}{r}
\operatorname{CostCap}_{i, t}=\alpha+\beta_{1} C C O N S_{i t}+\beta_{2} L I Q D_{i t}+\beta_{3} L E V R_{i t}+\beta_{4} R O A_{i t}+\beta_{5} S I Z E_{i t}+ \\
\beta_{6} R I S K P R_{i t}+\beta_{7} D P O F_{i t}+\beta_{8} M B_{i t}+\epsilon_{i t}
\end{array}
$$

Where, CostCap is a cost of capital of the firms $i$ at time $t$, CCONS is conditional conservatism which we measured from Basu (1997) and modified by Khan and Watts (2009). LIQD is liquidity of the firm, LEVR is leverage of the firm, ROA is return on assets of firm $i$ at time $t$, SIZE is firm size which is natural log of total assets of the firm, RISKPR is risk premium. DPOF is dividend payoff, MB is market to book ratio. Furthermore details of all variables are explained in Table 1.

To examine the influence of accounting acceptances of conservatism in decreasing the cost of capital, this study argued that conditional conservatism lessens cost of capital. This paper also presents that conservatism reduces dividend payoff, decreases cost of capital and may resolve agency conflict of dividend pay-out. In addition, this study sheds a light on cost of capital and conservatism relationship with performance by analysing firms performance variables in the model.

\section{Empirical Results}

We describe descriptive analyses and examine the correlation of independent and dependent variables. Therefore, we explain below, through regression estimation model of this research, relationship of conditional conservatism and cost of capital. This study investigates and examines by this empirical model the relation and enlightens the outcomes and consequences of this research. Table 4, present the regression estimation and conjecture the results and finding of the paper.

\section{Descriptive Statistics}

The mean and median values of the conditional conservatism (CCONS) are -0.0758 and -0.051 and ranges from a minimum and maximum of -78.914 to 21.531 respectively. The negative and positive values of CCONS variable indicate the negative earnings (bad news) 
and positive earnings (good news), accordingly. Conditional accounting conservatism descriptive statistics difficult to compare with prior research because researcher used different methods to measure accounting conservatism such as Givoly and Hayn (2000); Khan and Watts (2009), and Khalifa and Ben Othman (2015) documented mean and median values -0.047 and $-0.037,0.105$ and 0.097 and 0.381 and 0.134 respectively. Cost of capital (CostCap) mean, median and standard deviation (SD) values are $0.2018,0.1638$ and 0.1383 respectively.

\begin{tabular}{|c|c|c|c|c|c|c|}
\hline Variables & No. Obs & Mean & Median & SD & Min & Max \\
\hline CCONS & 21601 & -0.0758 & -0.0517 & 0.6497 & -78.914 & 21.531 \\
\hline CostCap & 7091 & 0.2018 & 0.1638 & 0.1383 & 0.0015 & 0.7985 \\
\hline DPOF & 20609 & 0.0654 & 0 & 0.1297 & 0 & 3.997 \\
\hline SIZE & 20608 & 21.601 & 21.409 & 1.3778 & 11.348 & 30.571 \\
\hline LEVR & 20608 & 0.5776 & 0.4872 & 6.2527 & 0.0017 & 877.26 \\
\hline ROA & 27413 & 0.8312 & 0.0341 & 142.66 & -2146.16 & 23509.7 \\
\hline RISKPR & 20421 & 0.4527 & 0.4421 & 0.2169 & 0 & 1 \\
\hline LIQD & 20609 & -0.3783 & -0.0736 & 5.6074 & -373.08 & -0.0005 \\
\hline MB & 6569 & 1.2523 & 1.6118 & 87.927 & -7072.81 & 238.72 \\
\hline \multicolumn{7}{|c|}{$\begin{array}{l}\text { Notes: This table shows descriptive of each variable of the study model } \\
\text { during the period } 2006 \text { to 2011. Its represents the number of observations } \\
\text { of each variable, mean, median, standard Deviation (SD), minimum and } \\
\text { maximum. CCONS is conditional conservatism) which is calculated from } \\
\text { Basu (1997) model which is amended by Khan and Watts (2009). CostCap } \\
\text { is cost of capital which is calculated from OJ-model (2005), } 2 \text { DPOF is } \\
\text { dividend payoff, SIZE is firm size and it's a natural log of total assets of } \\
\text { the firm, ROA is return on assets, RISKPR is risk premium, LIQD is } \\
\text { liquidity of the firm, MB is market to book ratio. }\end{array}$} \\
\hline
\end{tabular}

\section{Spearman Correlations Analysis}

Table 3 shows Spearman correlation among variables. Earlier, this paper analyse the regression investigation, scrutinize correlation of variables among each other. This paper used Spearman correlation test to examine the correlation of variables. Though, we expected that our data normally distributed. Correlations table presents that CCONS is significantly correlated with all variables except ROA, RISKPR and DPOF. Spearman correlation table reveals some exciting correlations between variables. Such as, conservatism (CCONS) and cost of capital (CostCap) are negatively associated each other (-0.1171). This negative association supports our hypothesis that conservatism lessens the cost of capital. Furthermore, conditional conservatism (CCONS) and dividend payoff (DPOF) variables are negatively correlated, which shows that conservatism reduces the dividend payoff. Overall most of our study variables are significantly correlated each other. Spearman correlation table also shows that variables are not highly correlated which caused of multicollinearity. Hence, we can report that no multicollinearity problem between independent and dependent variables. 
Table 3

Spearman correlation of all variables

\begin{tabular}{llllllllll}
\hline & CCONS & CostCap & LIQD & LEVR & ROA & SIZE & RISKPR & DPOF & MB \\
\hline CCONS & & & & & & & & & \\
CostCap & $-0.1171^{*}$ & & & & & & & & \\
LIQD & $0.2751^{*}$ & $-0.1495^{*}$ & & & & & & & \\
LEVR & $-0.0296^{*}$ & $0.2253^{*}$ & $-0.0730^{*}$ & & & & & & \\
ROA & 0.0199 & $-0.1848^{*}$ & $0.2795^{*}$ & $-0.3707^{*}$ & & & & & \\
SIZA & $-0.0576^{*}$ & $0.0882^{*}$ & $0.5238^{*}$ & $0.1964^{*}$ & $0.2106^{*}$ & & & & \\
RISKPR & -0.0035 & $0.0318^{*}$ & 0.0081 & $-0.0877^{*}$ & $-0.0713^{*}$ & $0.0257^{*}$ & & & \\
DPOF & -0.0045 & $-0.0696^{*}$ & $0.1269^{*}$ & $-0.1743^{*}$ & $0.4872^{*}$ & $0.2828^{*}$ & 0.0032 & & \\
MB & $0.2816^{*}$ & $-0.3166^{*}$ & $0.3594^{*}$ & $-0.1479^{*}$ & $0.1811^{*}$ & $-0.2509^{*}$ & $-0.0996^{*}$ & -0.0223 & \\
\hline
\end{tabular}

Notes: This table shows the spearman correlation among all variables CCONS is conditional conservatism which is evaluated from Basu (1997) model which amended by Khan and Watts (2009) CostCap is cost of capital which is calculated from OJ-model (2005),DPOF is dividend payoff, SIZE is firm size and it's a natural $\log$ of total assets, ROA is return on assets, RISKPR is risk premium, LIQD is liquidity of the firm, MB is market to book ratio. Spearmen correlation represents significant ${ }^{*}$ at $5 \%$ level.

\section{Regression Analysis}

This paper presents the results of conditional conservatism association with cost of capital as formulated from above model. Table 4 shows the regression analysis of conservatism and the cost of capital. In same vein, Francis et al. (2004); Chan et al. (2009); Artiach and Clarkson (2011); Lara et al. (2011); R. A. Lambert et al. (2011); Li (2015); Khalifa and Ben Othman (2015) investigated the conditional conservatism impact on cost of capital. Similarly, Guay and Verrecchia (2007) and Suijs (2008) also claimed that asymmetric timeliness of earnings (bad news) lessens the cost of capital. We approached conservatism and cost of capital association in different manners such as data sample and variables selection. We estimates model with year and industry fixed effect. Table 4 explains results of panel data estimation. We hypothesized that conditional conservatism lowers the cost of capital, accordingly, are also expecting negative association between conditional conservatism and cost of capital. Table 4 shows that conditional conservatism (CCONS) significant negatively related with cost of capital (CostCap). Conservatism (CCONS) negatively significant at $1 \%$ level (coeff. $=-0.0283$, $\mathrm{t}$-value $=-2.75$ ). This result suggests that we accept the hypothesis (H1) in the favour of that conservatism diminishes the cost of capital in Chinese firms. Furthermore, Table 4 represents that the cost of capital (CostCap) positively correlated with leverage (LEVR), return on assets (ROA), firm size (SIZE) and market to book ratio (MB) and all are significant at $1 \%$ level with (coeff. $=0.0143$, $\mathrm{t}$-value $=7.01)$, (coeff. $=0.0066, \mathrm{t}$-value $=6.09)$ and $($ coeff $=.0 .0073, \mathrm{t}$-value $=5.460)$ and $(\mathrm{co}-$ eff. $=0.0002$, $t$-value $=2.71)$ respectively. We were expecting negative correlation of cost of capital (CostCap) with return on assets (ROA), firm size (SIZE) and market to book ratio $(\mathrm{MB})$ because negative relation shows that lower the cost of capital then greater the return on assets(ROA), firm size (SIZE) and market to book ratio (MB), our results are vice versa. According to prior research Lara et al. (2011); Li (2015); Khalifa and Ben Othman (2015), we also found that leverage (LEVR) positively related with cost of capital (CostCap) which infers that leverage increases the cost of capital.

In line with Watts (2003); Francis et al. (2004); Chan et al. (2009); Artiach and Clarkson (2011); Lara et al. (2011); R. A. Lambert et al. (2011); Li (2015) dividend decrease the cost 
of capital, we also find negative significant relationship of dividend payoff (DPOF) and cost of capital (CostCap) and dividend payoff (DPOF) significant at $1 \%$ level with coeff. = -0.0801 and $\mathrm{t}$-value $=-5.42$.

Table 4

Results of regression model of the cost of capital

\begin{tabular}{lcc}
\hline Independent variables & Sign & Coefficients(t-value) \\
\hline CCONS & $(-)$ & $-0.0283(-2.75)^{* * *}$ \\
LIQD & $(+)$ & $0.0002(0.50)$ \\
LEVR & $(+)$ & $0.0143(7.01)^{* * *}$ \\
ROA & $(-)$ & $0.0066(6.09)^{* * *}$ \\
SIZE & $(-)$ & $0.0073(5.46)^{* * *}$ \\
RISKPR & $(+)$ & $0.0085(0.96)$ \\
DPOF & $(-)$ & $-0.0801(-5.42)^{* * *}$ \\
MB & $(-)$ & $0.0002(2.71)^{* * *}$ \\
Intercept & $-0.0501(-1.54)$ \\
No. Obs. & 6569 \\
R-Square & $0.132(13.2 \%)$ \\
\hline Notes: This table shows the results of regression analysis. Where CCONS \\
is conditional conservatism which is evaluated from Basu $(1997)$ model \\
which amended by Khan and Watts (2009). CostCap is cost of capital which \\
is calculated from OJ-model (2005), DPOF is dividend payoff, SIZE \\
is firm size and its natural log of total assets, ROA is return on assets, \\
RISKPR is risk premium, LIQD is liquidity of the firm, MB is market \\
to book ratio. These symbols show ${ }^{*}, * *$, ${ }^{* * *}$ significant at 10\%, 5\% \\
and 1\% level, respectively.
\end{tabular}

\section{Robust Test}

This study also performs the robust test to validate results. First, we estimate econometric model with alternative measure of the cost of capital, we measure the cost of capital by another method to verify or to check accuracy of our results. We used PEG ratio model (Easton, 2004) as an alternative measure of cost of capital. Unfortunately, our results are not consistent and second, we use 2SLS method which is introduced by Bollen (1996) to do robust analysis. In substitute valuation of conservatism and the cost of capital, we find somewhat same significant outcomes such as we got that conservatism decreases the cost of capital and dividend payoff (DPOF). Conservatism reduces the dividend payoff to shareholders; therefore this dividend reduction mechanism may help to decreases the risk for stakeholders (Mousa et al., 2014). Former researchers, (Ball et al., 2000; Ahmed, Billings, Morton, \& Stanford-Harris, 2002; Watts, 2003; Mousa et al., 2014); documented that conservatism resolve the agency conflict. Likewise previous research, these results depict that conservatism reduces agency problem. This study attained results according to the predictions and projected hypothesis.

\section{Conclusion}

The astute purpose of present paper to examines the consequences of accounting conservatism in emerging economy such as China. By using a sample data of 6569 A-share listed firms over the period 2002 to 2013, we examine the existence of conservatism in financial 
reporting system by employing Basu model. Further, we examine that timely recognition of losses effect on cost of capital. Paper outcome advocates that conditional conservatism reduces the cost of capital which corroborates our hypothesis that conservatism lessens the cost of capital. However, by employing 2SLS robust test method we also find that conservatism reduces the dividend payoff which may cause to resolve agency conflict.

This study finding and results may be useful for educational researchers, regulators and standard setters by enhancing our realisation of importance of accounting conservatism particularly in Chinese developing market. This research will stimulate academic researchers to further scrutinize and elaborate accounting conservatism and its economic consequences on emerging economy. The limitations of this article are first, due to lack of time and data this research limited to one emerging economy and second, it only applies one measurement of accounting conservatism. In future, by prolonging same vein of study and overcoming the limitations, we will analyse in detail that conditional accounting conservatism approach in financial reporting has influenced on cost of capital and will expand same study on international comparative analysis with numerous data sample and variables arrangement. In addition, we will more emphasize on that how accounting conservatism reduces the cost of capital by using different data sample and variables to depict stimulating research in same area. Furthermore, we will strive to enlighten the conservatism economic consequences and benefits with precise manners. 


\section{References}

Ahmed, A. S., Billings, B. K., Morton, R. M., \& Stanford-Harris, M. (2002). The role of accounting conservatism in mitigating bondholder-shareholder conflicts over dividend policy and in reducing debt costs. The Accounting Review, 77(4), 867-890.

Artiach, T. C., \& Clarkson, P. M. (2011). Disclosure, conservatism and the cost of equity capital: A review of the foundation literature. Accounting $\mathcal{E}$ Finance, 51(1), 2-49.

Bagnoli, M., \& Watts, S. G. (2005). Conservative accounting choices. Management Science, 51(5), 786-801.

Ball, R. (2001). Infrastructure requirements for an economically efficient system of public financial reporting and disclosure. Brookings-Wharton Papers on Financial Services, 2001(1), 127-169.

Ball, R., Kothari, S., \& Robin, A. (2000). The effect of international institutional factors on properties of accounting earnings. Journal of Accounting and Economics, 29(1), 1-51.

Ball, R., Robin, A., \& Wu, J. S. (2003). Incentives versus standards: Properties of accounting income in four East Asian countries. Journal of Accounting and Economics, 36(1-3), 235-270.

Ball, R., \& Shivakumar, L. (2005). Earnings quality in UK private firms: Comparative loss recognition timeliness. Journal of Accounting and Economics, 39(1), 83-128.

Basu, S. (1997). The conservatism principle and the asymmetric timeliness of earnings. Journal of Accounting and Economics, 24(1), 3-37.

Bliss, J. H. (1924). Management through accounts. Ronald Press Company.

Bollen, K. A. (1996). An alternative two stage least squares (2SLS) estimator for latent variable equations. Psychometrika, 61(1), 109-121.

Chan, A. L.-C., Lin, S. W., \& Strong, N. (2009). Accounting conservatism and the cost of equity capital: UK evidence. Managerial Finance, 35(4), 325-345.

Chen, B.-W., C, \& Zhu, S. (2012). Does conservative accounting matter to cash dividend policy? Retrieved from http://hrmars.com/hrmars_papers/Article_20_The Association_between_Accounting_Conservatism.pdf

Chen, Q., Hemmer, T., \& Zhang, Y. (2007). On the relation between conservatism in accounting standards and incentives for earnings management. Journal of Accounting Research, 45(3), 541-565.

Chung, R., Firth, M., \& Kim, J.-B. (2003). Auditor conservatism and reported earnings. Accounting and Business Research, 33(1), 19-32.

Easley, D., \& O'hara, M. (2004). Information and the cost of capital. The Journal of Finance, 59(4), 1553-1583.

Easton, P. D. (2004). PE ratios, PEG ratios, and estimating the implied expected rate of return on equity capital. The Accounting Review, 79(1), 73-95.

Francis, J., LaFond, R., Olsson, P. M., \& Schipper, K. (2004). Costs of equity and earnings attributes. The Accounting Review, 79(4), 967-1010.

Gao, P. (2011). A contracting approach to conservatism and earnings management. Working paper. University of Chicago.

Gietzmann, M. B., \& Trombetta, M. (2003). Disclosure interactions: Accounting policy choice and voluntary disclosure effects on the cost of raising outside capital. Ac- 
counting and Business Research, 33(3), 187-205.

Gigler, F., Kanodia, C., Sapra, H., \& Venugopalan, R. (2009). Accounting conservatism and the efficiency of debt contracts. Journal of Accounting Research, 47(3), 767-797.

Givoly, D., \& Hayn, C. (2000). The changing time-series properties of earnings, cash flows and accruals: Has financial reporting become more conservative? Journal of Accounting and Economics, 29(3), 287-320.

Gode, D., \& Mohanram, P. (2003). Inferring the cost of capital using the Ohlson-Juettner model. Review of Accounting Studies, 8(4), 399-431.

Grambovas, C. A., Giner, B., \& Christodoulou, D. (2006). Earnings conservatism: Panel data evidence from the European Union and the United States. Abacus, 42(3-4), 354378.

Guay, W. R., \& Verrecchia, R. E. (2007). Conservative disclosure. Working paper, University of Pennsylvania.

Hail, L., \& Leuz, C. (2007). Capital market effects of mandatory IFRS reporting in the EU: Empirical evidence.

Khalifa, M., \& Ben Othman, H. (2015). The effect of conservatism on cost of capital: Mena evidence. Applied Economics, 47(1), 71-87.

Khan, M., \& Watts, R. L. (2009). Estimation and empirical properties of a firm-year measure of accounting conservatism. Journal of Accounting and Economics, 48(2-3), 132150.

Kothari, S., Ramanna, K., \& Skinner, D. J. (2010). Implications for GAAP from an analysis of positive research in accounting. Journal of Accounting and Economics, 50(2-3), 246286.

Kwon, Y. K. (2005). Accounting conservatism and managerial incentives. Management Science, 51(11), 1626-1632.

Lafond, R., \& Roychowdhury, S. (2008). Managerial ownership and accounting conservatism. Journal of Accounting Research, 46(1), 101-135.

LaFond, R., \& Watts, R. L. (2008). The information role of conservatism. The Accounting Review, 83(2), 447-478.

Lambert, R., Leuz, C., \& Verrecchia, R. E. (2007). Accounting information, disclosure, and the cost of capital. Journal of Accounting Research, 45(2), 385-420.

Lambert, R. A., Leuz, C., \& Verrecchia, R. E. (2011). Information asymmetry, information precision, and the cost of capital. Review of Finance, 16(1), 1-29.

Lara, J. M. G., Osma, B. G., \& Penalva, F. (2011). Conditional conservatism and cost of capital. Review of Accounting Studies, 16(2), 247-271.

Li, X. (2015). Accounting conservatism and the cost of capital: An international analysis. Journal of Business Finance \& Accounting, 42(5-6), 555-582.

Mohammed, N. F., Ahmed, K., \& Ji, X.-d. (2010). Accounting conservatism, corporate governance and political influence: Evidence from Malaysia.

Mousa, G. A., et al. (2014). The association between accounting conservatism and cash dividends: Evidence from emerging markets. International Journal of Academic Research in Accounting, Finance and Management Sciences, 4(4), 210-220.

Ohlson, J. A., \& Juettner-Nauroth, B. E. (2005). Expected EPS and EPS growth as determinantsof value. Review of Accounting Studies, 10(2-3), 349-365. 
Ruch, G. W., \& Taylor, G. K. (2014). The effects of accounting conservatism on financial statements and financial statement users: A review of the literature. Available at SSRN 1931732.

Suijs, J. (2008). On the value relevance of asymmetric financial reporting policies. Journal of Accounting Research, 46(5), 1297-1321.

Watts, R. L. (2003). Conservatism in accounting part I: Explanations and implications. Accounting Horizons, 17(3), 207-221.

Xu, X., Wang, X., \& Han, N. (2012). Accounting conservatism, ultimate ownership and investment efficiency. China Finance Review International, 2(1), 53-77.

Zhang, C., \& Wu, S. (2011). Notice of retraction accounting conservatism and cost of equity capital- Evidence from China's security market. In International Conference on Business Management and Electronic Information. 